\title{
Evaluation of Budgeting Process for Infrastructure Investment Project in Manufacturing Companies
} (Case Study on PT. XXX)

\author{
*Hadyan Rifqi Antoro ${ }^{1}$, Mohamad Slamet Wibowo \\ ${ }^{1}$ University of Indonesia, Depok, Indonesia \\ ${ }^{2}$ University of Indonesia, Depok, Indonesia \\ *Corresponding author. Email: hrantoro@gmail.com
}

\begin{abstract}
In 2019, PT. XXX have over budget in their infrastructure project for over 40 billion Indonesian Rupiah. This makes it necessary to evaluate the existing budgeting process in the company in infrastructure development. Thisresearch aims to evaluate the project cost budget plan and control over the project budget plan that should be implemented by PT. XXX. The method used in this research is mixed method with a case study approach to the single case unit analysis. Data was collected using documentation, content analysis and interviews. The results ofthe evaluation of the budget plan that should be owned by PT. XXX indicates that there is a need for improvementin the project budget planning process and also in the procurement method. In addition, the evaluation results regarding the control of the budget plan owned by PT. XXX shows that the control over the project budget plan owned by PT. XXX is still ineffective. In the process of preparing the budget plan for the next project, PT. XXXmust ensure that the additional costs incurred in the project are included in the budgeting and in the process of controlling the budget plan for the next project. PT. XXX should also create a reporting tool which includes all the information needed by project manager in decision making.
\end{abstract}

Keywords: Human Resources, Netflix, Working Conditions, Job Content, Work Motivation.

\section{INTRODUCTION}

A budget is an instrument used by an organization in achieving its goals in matching plans with available resources. The primary function of using a budget is to provide management with projected activities necessary to achieve the stated objectives. So, if in the process of making the budget, especially for projects, then the purpose of making the budget cannot be achieved [1].

The Budget Plan for a project is also essential in project implementation. In addition to the budget as an instrument for controlling a project, [2] explains that a successful project is a project that uses Project Management well.
The explains that Project Management is the application of knowledge, skills, tools, and techniques to project activities to fulfill project requirements [3].

Based on data obtained from the Department of Capital Project PT. XXX (2019) in Table 1 below shows that 7 of the 18 projects that have been carried out are in over budget status, i.e., actual costs exceed the existing Budget Plan. This shows that there is ineffectiveness in managing the predetermined budget. In addition, based on the initial interviews that have been conducted with the Technical Manager and National Project Manager of PT. XXX on July 12, 2019, it was said that 2 of the seven projects were still being worked on and not yet fully completed. 
Table 1. PT. XXX Capital Project Reporting - 31 December 2019

\begin{tabular}{|c|c|c|c|c|}
\hline No & Project Name & $\begin{array}{l}\text { Approved Budget } \\
\text { (in Million Rupiah) }\end{array}$ & $\begin{array}{c}\text { Total Actual } \\
\text { Spending Cost (in } \\
\text { Million Rupiah) }\end{array}$ & Percentage \\
\hline 1 & Project A & $19,700.00$ & $1,001.93$ & $5 \%$ \\
\hline 2 & Project B & $87,000.00$ & $88,282.97$ & $101 \%$ \\
\hline 3 & Project C & $183,700.00$ & $187,693.99$ & $102 \%$ \\
\hline 4 & Project D & $349,000.00$ & $350,340.52$ & $100 \%$ \\
\hline 5 & Project E & $246,165.83$ & $248,131.61$ & $101 \%$ \\
\hline 6 & Project $\mathrm{F}$ & $48,600.00$ & $57,341.18$ & $118 \%$ \\
\hline 7 & Project G & $403,000.00$ & $312,670.93$ & $78 \%$ \\
\hline 8 & Project $\mathrm{H}$ & $227,400.00$ & $240,032.38$ & $106 \%$ \\
\hline 9 & Project I & $140,800.00$ & $114,814.96$ & $82 \%$ \\
\hline 10 & Project $\mathrm{J}$ & $620,400.00$ & $497,288.11$ & $80 \%$ \\
\hline 11 & Project K & $119,900.00$ & $133,060.87$ & $111 \%$ \\
\hline 12 & Project L & $127,000.00$ & $112,691.54$ & $89 \%$ \\
\hline 13 & Project M & $317,900.00$ & $223,916.86$ & $70 \%$ \\
\hline 14 & Project N & $330,000.00$ & $326,961.99$ & $99 \%$ \\
\hline 15 & Project O & $126,000.00$ & $117,481.56$ & $93 \%$ \\
\hline 16 & Project P & $52,100.00$ & $55,362.93$ & $106 \%$ \\
\hline 17 & Project Q & $75,300.00$ & $71,412.16$ & $95 \%$ \\
\hline 18 & Project R & $350,000.00$ & $294,756.80$ & $84 \%$ \\
\hline
\end{tabular}

The explain that a reasonable budget will increase the efficiency and effectiveness of the company [4]. In addition, according to [5], project success is related to the efficiency applied during the project. Efficiency is meant here is how the project is completed according to a predetermined schedule and the use of a budget following the Budget Plan that has been set before the project is implemented. This causes the need to evaluate the project cost budget at PT XXX.

Based on the explanation above, this research was conducted to evaluate the project budget plan and evaluate the control of the project budget plan that PT XXX should implement. This objective is used to answer the actual design of the project budget plan and control that PT. XXX should implement.

Similar research has been conducted on project budget control, project success, and project management. One research on the particular topic is research by [2] which explains the relationship between project management performance and project success. They found that project management performance had a positive relationship with the success of a project within an organization in the United Arab Emirates. In addition, [6] researched time and cost overruns in the United Arab Emirates (UAE) construction industry. In the research, they explain five main reasons that cause the time and cost overrun to occur: variations in design, poor cost estimations, delays in client decision-making, client financial constraints, and inappropriate procurement methods. Research from [7] finds that the success of a megaproject is distinguished by three main elements: a clear strategic vision, total alignment, and adaptability to complexity.

Unlike the previous research, this study is done in a case study on a manufacturing company in Indonesia. In addition, this study uses variance analysis and project management theory as written by [3]. The result of this study is that there will be an 
evaluation of the project budget plan and control of the project budget plan to create better control over the project budget plan to create an efficient project in terms of cost use and project results. Moreover, this study is expected to provide insights into the use of variance analysis or provide a new outlook and insights regarding the application of variance analysis and project management theory.

\section{LITERATURE REVIEW}

The explained that budget is a quantitative plan for the future expressed in physical or financial terms [4]. In addition, they explained that when used for planning, budget is a method for translating organizational goals and strategies into operational terms, and budget is also used as an organizational control tool. They also defined control as setting standards, receiving feedback on actual performance, and taking corrective action on the results of that feedback.

[4] further explained that a budget can be used to check the efficiency and effectiveness of a company. According to them, efficiency is achieved when a business process is carried out in the best possible way with little to no waste. A flexible budget assesses the manager's efficiency since it compares the actual costs for a given level of output with budgeted costs for the same level. Meanwhile, according to [4], effectiveness means that a manager achieves or exceeds the goals described by a static budget. Thus, it can be concluded that efficiency examines how well the work is done, and effectiveness examines whether excellent work is being done.

A project needs to make a budget for the costs to be carried out. In addition, it is also essential for a project to manage all aspects of the project so that it can run smoothly. [3] defines a project as a temporary effort undertaken to create a unique product, service, or outcome. The temporary nature of the project indicates that the project has a definite beginning and end. In addition, they also explain that project management (PM) is the application of knowledge, skills, tools, and techniques to project activities to meet the project requirements.

Several studies define the success of PM as seen from how a project can meet the targets and deliver the quality that has been planned from the beginning. Following that, [5] stated that there are four dimensions in the success of PM, namely:

1. Project Efficiency. In this dimension, project efficiency can be measured with whether the schedule objectives of the project are achieved or not and whether the budget plan objectives of the project are achieved or not.

2. Impact on consumers (users). In this dimension, the success can be measured based on:

a) Whether the project is already following the functional performance planned from the beginning or not.

b) Whether the technical specification is appropriate or not.

c) Whether the project addresses user problems and fulfills user needs or not.

d) Whether the users use the project or not.

e) Whether the users feel satisfied with the results of the completed project or not.

3) Business success. In this dimension, the success is measured based on the commercial success and whether the project can create an even larger market share or not.

4) Preparing for the future. Each project has its specific dimensions, and their relative importance will vary. In this dimension, the success is measured based on:

a) Whether the project can open a new market or not,

b) Whether the project can deliver a new product line or not, and

c) Whether the project can develop new technology or not.

However, [5] also explained that to assess the success of a project, one needs to understand the different dimensions and deal with different time horizons from very short to very long. To be able to find out how a project cost budget is used efficiently and effectively, it can usually be done by analyzing the form of variance analysis [3] explained that the variance analysis in the budget control system is carried out by comparing actual costs with budgeted costs by calculating the existing variance, namely the difference between actual and planned costs for the actual activity level. Meanwhile, [3] defines variance analysis as reviewing the difference between the planned and actual performance. According to PMI, this includes estimated duration, cost, resource utilization, resource level, technical performance, and other metrics.

\subsection{Critical Framework}

The framework of thought in this research can beseen in Figure 1 below: 


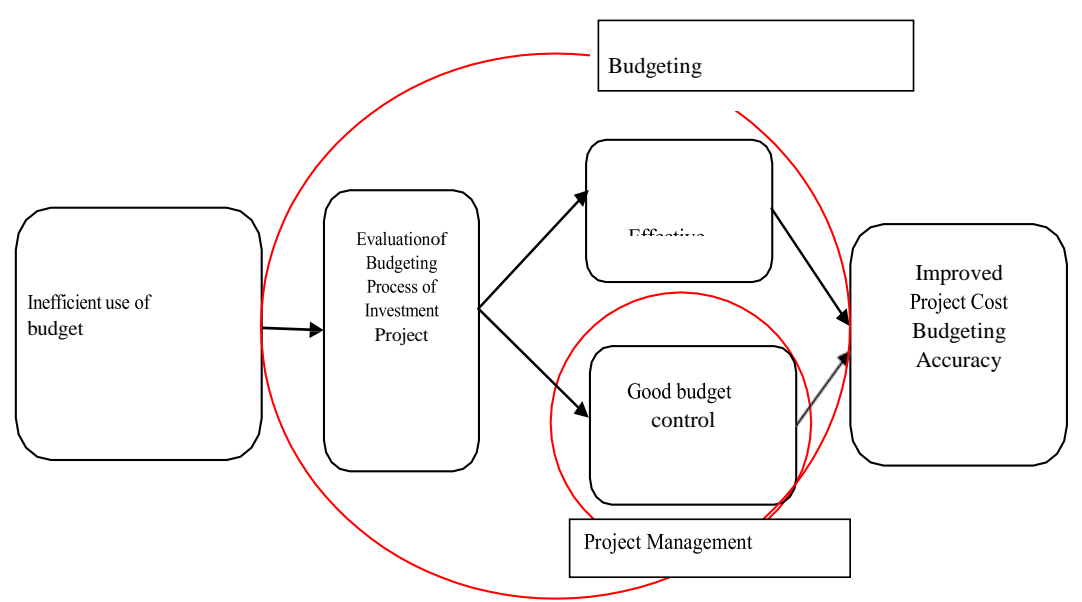

Figure 1. Theoretical Thinking Framework

\section{METHODOLOGY}

\subsection{Research Strategy}

The research strategy in this study was carried out using a case study approach conducted at PT. XXX. [8] explained that a case study is another type of qualitative research. In addition, they stated that a case study differs from other types because it is an intensive analysis and description of a unit or system that is limited by space and time. [9] describes the unit of analysis as the element in which the data are analyzed and for which the findings are reported. In most social and behavioral science research, the individual is the unit of data collection and analysis [9]. The unit of analysis used in this study are documents, data, and interview results regarding budgeting and controlling over the PT. XXX budget.

\subsection{Research Approach}

The research approach of this study is a mixedmethod approach which is a mix of qualitative and quantitative methods. The mixed-method approach is defined as research conducted by researchers which uses qualitative and quantitative approach methodologies to answer the research questions. This approach more often provides research results that are more informative, complete, and balanced [10].

This study also uses a sequential quantitativequalitative approach to gain richer analysis results that can help answer the research questions. [10] describes sequential mixed analysis as an analytical method that uses various approaches to data collection, analysis, and inference which is carried out in a sequence of phases. In this approach, the data analysis begins before all data is collected.
According to [10], one of the types of this approach is a sequential quantitative-qualitative approach. This means that when the quantitative data analysis step is carried out, it will be followed by the qualitative data analysis step.

\subsection{Data Collection Technique}

The type of data in this study is primary data. The data collected in this research case study was carried out using research instruments, namely documentation, content analysis, and interviews. This kind of data is used since this type of research instrument can answer the phenomenon of excavation in making and managing a reasonable budget. According to [11], primary data is the data that the researchers collect directly for the specific purpose of the study. [10] explained what is included in primary data, namely:

1) Interview and Focus Group Discussions.

2) Observation.

3) Natural conversations.

The data collection step in this study began with the documentation of historical data regarding the budget process for submitting capital expenditure (Expense Budget Plan) by the project manager of PT. XXX. The data used in this study must meet the following requirements:

1) The budget and project budget usage data are from the projects running in 2019-2020.

2) The status of the use of the project budget in the data obtained is within the status of exceeding the project budget that PT. XXX.

After all the data was obtained, the researcher analyzed the data with the analysis described in the next section. Then after the data had been documented, content analysis was carried out so that 
the data could provide information that could answer the research questions. The last step in collecting data from this research was an interview considering the purpose of this research is to evaluate the Project Budget Plan (RAB) implemented by PT. XXX and evaluate the control of the Project RAB, which PT. XXX should own.

\subsection{Data Analysis Technique}

\subsubsection{Variance Analysis}

Variance analysis used in this study is variance analysis based on Cost Accounting and [3] which includes five analyses, namely:

1) Static Variance Budget The formula for this variance is:

Static variance budget $=$ Actual cost result - Cost value of static budget

2) Schedule Variance (SV) The formula for this variance is:

$S V=E V-P V$

Explanation:

$\mathrm{SV}$ is schedule variance

EV (Earned Value) is the measurement of completed work that is noted as a percentage in the budget that has been approved for the work (percentage of work completed $\mathrm{x}$ total budget approved).

PV (Planned Value) is the total budget approved for scheduled work.

\section{3) Cost Variance (CV)}

The formula for this variance is:

$C V=E V-A C$

Explanation:

$\mathrm{CV}$ is cost variance.

AC (Actual Cost) is the actual costs incurred for work performed on activity over a specific time.

4) Cost Performance Index (CPI) The formula for CPI is:

$C P I=E V / A C$

Explanation:

CPI is the cost performance index.

5) Variance at Completion (VAC) The formula for this variance is:

$V A C=B A C-E A C$
Explanation:

VAC is variance at completion.

BAC (Budget at Completion) is the total of all the budgets assigned to the work to be performed (total project budget).

EAC (Estimate at Completion) is the total expected cost to complete all work that is noted as the total of actual costs to date and the estimation for completing them. Calculating EAC is Budget at Completion (BAC) divided by Cost Performance Index (CPI).

\subsubsection{Descriptive Content Analysis}

According to Foresight enrich Research Infrastructure Impact Assessment Methodology [12] in their website, the descriptive content analysis examines quantitative and qualitative data collected through methods, such as document analysis, interviews, or surveys to summarize the information content of the data about the research question. The information content is presented in a straight and descriptive summary that is structured according to the research needs. Moreover, [12] also explains that the data sources for descriptive content analysis are from the qualitative and quantitative information gathered previously [12].

\subsubsection{Thematic Content Analysis}

According to [10], the thematic analysis aims to understand the range of responses, themes, discourses (speech or dialogue), etc., in the corpus (quantity) of data. In addition, thematic analysis is usually inductive, but it can also be deductive. Moreover, [10] stated that thematic analysis focuses more on qualitative corpus data. However, it can also be used for open-ended responses, such as open surveys.

In this study, after the analysis with variance analysis, content analysis, and thematic analysis was conducted, a conclusion was made using the available theory to answer the research questions about how the good Project Budget Plan (RAB) is for PT. XXX and also about the control of the Project Budget Plan that PT. XXX. 
Table 2. Project Budget Plan (RAB) is for PT. XXX

\begin{tabular}{|c|c|c|c|c|c|}
\hline No. & Cost Information & $\begin{array}{l}\text { Cost Budget Value (A) } \\
\text { (in million rupiah) }\end{array}$ & \multicolumn{2}{|c|}{$\begin{array}{l}\text { Actual Cost Value (B) } \\
\text { (in million rupiah) }\end{array}$} & $\begin{array}{l}\text { Static Budget Variance (C) } \\
\text { C= B- A }\end{array}$ \\
\hline 1 & Solar Panel Equipment & $\operatorname{Rp} 71,887$ & \multicolumn{2}{|c|}{$\operatorname{Rp} 74,267$} & $\mathrm{Rp2}, 379 \mathrm{U}$ \\
\hline \multirow[t]{2}{*}{2} & PV Inverter & $\operatorname{Rp} 13,243$ & \multicolumn{2}{|c|}{ Rp 12,684 } & - Rp 558 F \\
\hline & Components & & & & \\
\hline \multirow[t]{3}{*}{3} & Contingency & \multirow[t]{2}{*}{$\mathrm{Rp} \quad 1,869$} & \multirow{2}{*}{\multicolumn{2}{|c|}{$\mathrm{Rp}$}} & \multirow[t]{3}{*}{ - Rp1,869 F } \\
\hline & Additional & & & & \\
\hline & Bud & & & & \\
\hline \multirow[t]{3}{*}{4} & $\begin{array}{l}\text { get caused by project } \\
\text { delays and is used to }\end{array}$ & \multirow[t]{3}{*}{ Rp $\quad 7,200$} & \multirow[t]{3}{*}{$\mathrm{Rp}$} & \multirow[t]{3}{*}{7,057} & \multirow[t]{8}{*}{ - Rp 142 F } \\
\hline & $\begin{array}{l}\text { cover additional costs } \\
\text { for the } \\
\text { project delays }\end{array}$ & & & & \\
\hline & exchan & & & & \\
\hline \multirow[t]{5}{*}{5} & payment gefees for & \multirow[t]{5}{*}{$\mathrm{Rp}$} & \multirow[t]{5}{*}{$\mathrm{Rp}$} & \multirow[t]{5}{*}{358} & \\
\hline & purchasin solar panel & & & & \\
\hline & g & & & & \\
\hline & equipme & & & & \\
\hline & $\mathrm{nt}$ & & & & \\
\hline 6 & Capitalized labor costs & $\mathrm{Rp}$ & $\mathrm{Rp}$ & 174 & Rp174 U \\
\hline 7 & Import duties & $\mathrm{Rp}$ & $\mathrm{Rp}$ & 333 & Rp333 U \\
\hline \multirow[t]{2}{*}{8} & \multirow[t]{2}{*}{$\begin{array}{l}\text { Equipment storage } \\
\text { costs }\end{array}$} & \multirow[t]{2}{*}{$\mathrm{Rp}$} & \multirow[t]{2}{*}{$\mathrm{Rp}$} & 544 & \\
\hline & & & & & Rp544 U \\
\hline \multicolumn{2}{|l|}{ Total } & Rp94,200 & \multicolumn{2}{|c|}{ Rp95,419 } & Rp1,219U \\
\hline
\end{tabular}

Based on the data that has been processed in Table 2 above, it is found that there are unfavorable variances of 1.22 billion rupiahs in total. This means there is an increase in fixed costs for the acquisition of assets of 1.22 billion rupiahs, affecting the decrease in relative operating income to the budgeted amount.

In detail, the value of the unfavorable variance that occurred was caused by the 3.79 billion rupiahs of unfavorable variances experienced due to the difference in budgeted costs and actual costs for purchasing the solar panel equipment, foreign exchange payment fees, capitalized labor costs, and import duties. Meanwhile, in the cost of PV inverter components, contingency costs, and additional budget costs, there are favorable variances of 2.57 billion rupiahs.

Table 3. Variance Analysis Result of Project Management Institute Project B

\begin{tabular}{|c|c|c|c|}
\hline No & Variance Analysis & Analysis Result & Result Interpretation \\
\hline 1 & Schedule Variance & -Rp13,188,000,000 & Project lags behind the schedule \\
\hline 2 & Cost Variance & -Rp14,407,671,894 & $\begin{array}{l}\text { The actual cost of the project is more than } \\
\text { the planned project cost }\end{array}$ \\
\hline 3 & Cost Performance Index & 0.85 & Project costs more than planned cost \\
\hline 4 & Variance at Completion & -Rp16,753,106,853 & Project costs more than planned cost \\
\hline
\end{tabular}


Based on the analysis results in Table 3 above, it can be seen that there was a project delay from the financial side compared to the previously planned schedule in the schedule variance in June. This is indicated by a negative 13 billion rupiahs that can be seen in the result of the analysis of variance. Moreover, based on cost variance analysis, it is found that the actual cost of the project in that month had exceeded the project cost that was planned to be issued. This is indicated by a negative 14 billion rupiahs in the analysis of variance result.
Meanwhile, the result of the cost performance index (CPI) analysis shows that the actual cost of the project that has been incurred exceeded the planned cost. This is indicated by the CPI value of 0.85 below 1.0. Finally, the variance at completion (VAC) result is similar to the CPI because it gives a negative result of 16 billion rupiahs. This means that the VAC also implies that the project's actual cost will be greater than the previously planned cost when the project is completed.

Table 4. Analysis Result of Static Budget Variance of Project C

\begin{tabular}{|c|c|c|c|c|}
\hline No & Cost Information & $\begin{array}{c}\text { Cost Budget Value }(A) \\
\text { (in rupiah) }\end{array}$ & $\begin{array}{c}\text { Actual Cost Value (B) } \\
\text { (in rupiah) }\end{array}$ & $\begin{array}{c}\text { Static Budget Variance } \\
\text { (C) } \\
\text { C }=\text { B-A }\end{array}$ \\
\hline 1 & LS machine tools & Rp140,100,000,000 & Rp. $141,346,607,577$ & Rp. $1,246,607,577 \cup$ \\
\hline 2 & LS infrastructure & Rp 26,882,000,000 & $42,353,034,787$ & $\operatorname{Rp} 15,471,034,787 \cup$ \\
\hline 3 & Contingency & $\operatorname{Rp} 16,720,000,000$ & - & - Rp. $16,720,000,000$ F \\
\hline 4 & Additional budget & Rp 6,300,000,000 & - & - Rp. 6,300,000,000 F \\
\hline 5 & $\begin{array}{l}\text { Foreign exchange } \\
\text { payment fee }\end{array}$ & - & Rp. 6,778,229,718 & Rp. 6,778,229,718 U \\
\hline 6 & $\begin{array}{l}\text { Capitalized labor } \\
\text { cost }\end{array}$ & - & Rp. 538,768,794 & Rp. 538,768,794 U \\
\hline 7 & Import duties & - & Rp. 592,940,715 & Rp. 592,940,715 U \\
\hline & Total & Rp190,002,000,000 & Rp. $191,609,581,591$ & Rp. $1,607,581,591 \mathrm{U}$ \\
\hline
\end{tabular}

Based on the data that has been processed in Table 4 above, it is found that there are unfavorable variances of 1.60 billion rupiahs in total. This means an additional fixed cost of an asset acquisition of 1.60 billion rupiahs will affect the decrease in relative operating income to the budgeted amount. The value of unfavorable variances that occurred was caused by 24.6 billion rupiahs of unfavorable variances experienced due to the differences in budgeted costs and actual costs for purchasing LS machine tools, LS infrastructure costs, foreign exchange payment fees, capitalized labor costs, and import duties. Meanwhile, contingency and additional budget costs have favorable variances of 23 billion rupiahs.

Table 5. Variance Analysis Result of Project Management Institute Project C

\begin{tabular}{llll}
\hline No & Variance Analysis & Analysis Result & Result Interpretation \\
\hline 1 & Schedule Variance & $-\mathrm{Rp} 3,800,040,000$ & Project lags behind the schedule
\end{tabular}


2 Cost Variance

$-\operatorname{Rp} 5,407,621,591$

3 Cost Performance Index

0.97

$4 \quad$ Variance at Completion
$-\operatorname{Rp} 5,517,981,215$
The actual cost of the project is more than the planned project cost

Project costs more than planned cost

Project costs more than planned cost
Based on the analysis result in Table 5 above, it can be seen that there was a project delay from the financial perspective compared to the previously planned schedule in the schedule variance in June. This is indicated by a negative 3.8 billion rupiahs in the analysis of variance result. Furthermore, based on the cost variance analysis, it is found that the actual cost of the project in that month had exceeded the project cost that was planned to be issued. This is indicated by a negative 5.4 billion rupiahs in the analysis of variance result. Meanwhile, the result of the cost performance index (CPI) analysis shows that the actual cost of the project that has been incurred exceeded the planned cost.

This is indicated by the CPI value of 0.97 below 1.0. Finally, the variance at completion (VAC) shows a similar result to the CPI because it gives a negative result of 5.5 billion rupiahs. This means that the VAC also implies that the project's actual cost will be greater than the previously planned cost when the project is completed.

The process of submitting a project RAB and its approval begins with an analysis of infrastructure needs interpreted from the company's growth determined in its business plan. The quantitative data discussed previously becomes the basis for the following interview results. The interview began with a discussion on the business processes carried out by PT. XXX in preparing the project budget plan. The three informants gave the same information about this business process.

Furthermore, the three informants explained that the company's business plan would then be reduced to an annual business plan which can help to give information about the capacity that needs to be added for that year. From this information, the company's infrastructure management team will then analyze the capacity in that year that needs to be built to support future business. The three informants exemplified the capacity needs in question, such as the construction of a new production line or a new distribution center.

This information is then given to the capital project division. After receiving the information that additional new capacity is needed, the capital project division will begin a feasibility study in the field and develop what needs are needed to build the new capacity. Then, after all the information is obtained, they will begin preparing the project's budget plan (RAB). The three informants explained that in preparing the $\mathrm{RAB}$ for projects, they usually use information based on construction prices in the market that are available online or use the information on the latest project development figures to which they have added the inflation factor.

Furthermore, the project $\mathrm{RAB}$ will be given to the capital expenditure team, which is part of the finance division, to process the investment calculation to obtain the investment's ROI, WACC, ROCE, and Payback period values. Suppose the results of the analysis show good results. In that case, the proposal will be submitted to the board of directors in Indonesia for further submission to the board of directors of group companies in Australia for approval. After the proposal is approved, the project administration matters in the system will be carried out. The project can start according to the schedule made during the proposal preparation.

Informants $\mathrm{A}$ and $\mathrm{B}$ explained that the business process in the project $\mathrm{RAB}$ preparation and the submission of approval for the project proposal was already adequate. However, informant B explained that when compared to companies whose core business is construction, there will be differences in terms of the effectiveness of the project RAB preparation process. According to him, the supporting tools for construction companies in preparing the project $\mathrm{RAB}$ will be more different from PT. XXX.

Informant A explained that there are three reasons as to why project cost overruns occur:

1) Poor budget accuracy and no cost forecasting in the months ahead of the project running.

2) Concern from management, including the project manager, in running the project. According to informant A, there is a lack of control over additional costs that are not essential in delivering results for the project.

3) Selection of specifications that exceed the predetermined scope and are not observed further during the procurement process. 
Slightly different from informant A, informant $\mathrm{B}$ and $\mathrm{C}$ explained that the reasons why project cost overruns occurred were as follows:

1) There are things outside the project plan that have been considered.

2) The procurement process is still unable to accommodate the best decision-making.

3) There is a handover of the project execution in the middle of the work. The project turns out to have a dissatisfactory project planning process and a low project cost.

4) The high cost of foreign exchange was caused by the unfavorable economic conditions in early 2020.

During the interview, the informants also explained the control and monitoring process carried out by PT. XXX in the use of the project budget. Informants $\mathrm{A}$ and $\mathrm{B}$ stated that the control and monitoring of the budget had been managed by the capital expenditure team, which is part of the finance division. Informant B further explained that the control had been carried out by making reports on the use of the budget at the summary level only, and these reports are provided monthly. However, informant A mentioned that the report received by the capital project division was not always on time. Sometimes, the report in a particular month was not sent to the capital project division as the budget user in the field. Due to the irregular frequency of the reports, informant $\mathrm{A}$ and $\mathrm{B}$ explained that sometimes the information they received was inaccurate to use as a basis for making decisions. Information A described an example of this in the following quote:

"Sometimes, we would get the financial information about the project two months after the decision is made. As a result, it would already be too late to take action in correcting the wrong decisions that have been made. For example, there are accruals for financial transactions that do not reflect the actual conditions; this causes a misunderstanding for the financial results of the project that has occurred..." (Informant A, 2020).

Furthermore, informant B gave another example for the impact of the less timely and less accurate control on the following quote:

"Sometimes, the forecasting has become stale. We do not know that we are already on a certain level. So, we do not have close control. We also have no control over our project cash flow, and we cannot notify the account payable team whether the project invoice can be paid now or later. We have no reason to make the right decision since the information flowtained is less reliable. We cannot check the daily project invoice liability of the updated reports only once a month. As a result, we cannot ensure the health of the project financially at the right time..." (Informant B, 2020).

As the executor in the field, Informant $\mathrm{C}$ did not directly receive the report on using the project budget. Informant $\mathrm{C}$ explained that the informant's superiors only received the report on the control of the budget usage. Therefore, the three informants agreed that they felt that the budget usage control and monitoring were very ineffective since the information they got was not on time. Once they get the information, a decision has been taken.

Based on the results of the interviews, several themes appear in the results of this study, which are as follows:

1) Budget swelling is caused by costs other than those already planned in the project RAB.

2) The procurement process still needs improvement.

3) Ineffective control and monitoring processes lead to inaccurate decisionmaking.

The success of a project is determined by the project management performance in delivering the project so that a project can meet the targets and deliver the quality that has been planned from the beginning [2] In addition, [4] explained that budget is a quantitative plan for the future of a company. Good budgeting will provide results that can help the company achieve its targets.

In this study, the quantitative approach results obtained from the documentation data, content analysis, and variance analysis show that the preparation of the project budget plan is still not proper because there were swelling in the costs that have been incurred. Based on the documentation and content analysis results, PT XXX provided the project cost budget structure is only a big picture of what costs are budgeted and spent on projects, namely Project B and C. Although the quantitative data obtained is very minimal in detail, the analysis results, both content analysis and variance analysis found that there were still some cost elements that were not included in the planning and budgeting stages of the project implementation.

Looking at the results of the VAC (Variance at Completion) analysis, it is found that when the project is completed, there will still be the possibility of additional costs that might add to the swelling of the project costs. In addition, based on the results of variance analysis, it is found that the two projects that became the object of the analysis experienced delays in their implementation compared to the 
schedule that had been planned. These results indicate that processes need to be improved so that PT. XXX can obtain the quality and costs following what has been planned in the future. According to [3], effective project management through project management can be realized by helping organizations achieve their goals, not harming stakeholders, and managing obstacles encountered during project work.

The interview results found that the delay in project completion was due to a poor initial planning process in project $\mathrm{B}$. In the descriptive and thematic content analysis, Informant B stated that project B was a project whose management was transferred from the operating unit to the capital project division. In addition, several processes were not carried out by the operating unit, and one of them is a lack of project feasibility studies before the project is implemented.

Another factor that turned out to be the cost swelling is the improper procurement process. This caused additional costs that were not included in the previous procurement process. These costs include insurance costs, import duties, and storage costs. Aside from the costs, there is also a significant impact on project $\mathrm{C}$ caused by the costs of paying in foreign exchange. According to the informant, this happened due to the COVID-19 pandemic, which caused uncertainty in March 2020. This uncertainty has made project $\mathrm{C}$ an additional impact of 2 billion rupiahs in forex payment fees due to the soaring foreign exchange rate. All of this follows the previous research conducted by [6]. They found that one of the causes of the swelling was poor cost estimation and inappropriate procurement methods.

The quantitative and qualitative analysis results indicate that there needs to be an improvement in the project budget planning process and the procurement method. This needs to be done so that PT. XXX achieves success based not only on the quality that can be delivered well but also on managing the project costs that are following what has been budgeted. According to [3], monitoring and controlling are factors in project management's five essential process groups. This happens because if one factor changes, it will affect other factors.

Furthermore, the results of this study show that there are less effective controls at PT. XXX. This was obtained from the interviews conducted with the three informants in which they felt that they could not provide good decision-making due to the lack of information quality. In addition, the unavailability of appropriate information is also a factor that causes the inability to make the right decisions. According to [13], forecasting or estimating costs in controlling is essential to help the decision-making process be even better.

The interview results also show that the frequency of reports on RAB control was still inconsistent. In addition, only the top management gets the information that should be shared with the parties who need it for decision-making in the field. According to [14], the success of a project can be seen from how the critical performance processes can affect the transfer of knowledge and information within the project environment. A reasonable control and monitoring tool is needed to carry this knowledge and information transfer process properly. Hansen and Mowen also stated that one of the purposes of budgeting is to provide information to improve decision-making. However, this cannot be done if the budget control and monitoring process is not carried out correctly. Also stated that the success of a project is based on three main elements, namely a clear strategic vision, total alignment, and adaptability to complexity [7]. A good control report will also align with the project implementation process. This will also help the project manager carry out the strategic vision and adapt if there is a complexity to the costs that arise.

\section{CONCLUSION}

Based on the analysis results, it can be concluded that the evaluation of the budget plan (RAB) that PT. XXX should own indicates that there is a need for improvement in the project budget planning process and the procurement methods. This is because, based on the results of the variance analysis, both project $\mathrm{B}$ and project $\mathrm{C}$ that PT. XXX manages had actual cost overruns of 1.2 billion rupiahs and 1.6 billion rupiahs in June 2020. In addition, based on the interview results, it is found that the swelling was caused by costs that were not included in preparing the project RAB. These not covered costs came from the foreign exchange payment process and costs not covered during the procurement process, such as insurance costs, storage fees, and import duties.

Furthermore, the evaluation results of the RAB control that PT. XXX should own also suggested that the control over the project RAB owned by PT. XXX is still less effective. This was revealed from the interview results, which show that the control and monitoring of the project cost budget usage were still unable to help the project manager make accurate and appropriate decisions for the company. [3] stated that the project control should be carried out periodically and should assist the project managers in making decisions so that the projects can be completed following the approved budget plan 
(RAB). Another evaluation is that the report that controls the project RAB does not provide the information needed by the project management as the project executor in the field. In addition, the reports on project $\mathrm{RAB}$ control were not available on time and were only given to division heads and department heads. This makes the project managers in the field unaware of the project budget status, and as a result, they cannot make the right cost decisions in the field.

Based on the conclusion above, there are several recommendations for PT. XXX, which are as follows:

1) In preparing the $\mathrm{RAB}$ for the next project, $\mathrm{PT}$. XXX must ensure that additional costs incurred in the project, such as costs for foreign exchange payments, can be included in the project cost budget. In addition, there should also be hedging carried out for these costs to minimize the risk that exists on the exposure of payments using these foreign currencies. Moreover, there is a need for improvements in the procurement process. Additional costs that should be covered during the procurement tender process are included in the bids given by the vendor.

2) In the process of controlling the RAB for the next project, PT. XXX is expected to be able to create a reporting tool that includes all the information needed by the project management, such as information on commitments that have been issued to vendors and how much has been approved, information on actual payments that have been made, and information on estimation for future payments or future commitments.

In the implementation of the research, several limitations caused the research cannot be carried out optimally. Some of the limitations that this research faced are as follows:

1) The current state of the COVID-19 pandemic made it impossible for the author to find and explore potential informants for the research. This national disaster created constraints in data collection, and the data collection process was not optimal.

2) Due to the limitations of the research object, this research only focuses on the capital project division in the preparation of the project budget plan and project budget management.

3) Limitations in data collection methods and analytical methods are also one of the limitations in this study.
Based on the research limitations above, there are several suggestions for the following research, which are as follows:

1) Involving and exploring other informants to enrich the research results.

2) Focusing not only on one project implementing division but also ensuring that information is obtained from other divisions involved in preparing the project budget plan and budget management.

3) Performing additional data collection methods, such as observation, etc., and adding other analytical methods to enrich the research analysis results.

\section{AUTHORS' CONTRIBUTIONS}

The previous research explained the use and controlof controls as a success factor for a project, while this research describes the evaluation of the project budgetused in order to increase the accuracy of the project budget. The results of the research are expected to provide references and contributions regarding good project budget control. In addition, the results of this research are expected to support the application of project management theory and provide insight into theuse of variance analysis or provide new views and insights regarding the application of variance analysis and project management theory. In addition, this research can provide comprehensive guidance for the community and other business people in carrying out good project budget control.

\section{REFERENCES}

[1] L. Imeokparia, O. A. Osun, and T. S. Afolabi, "Budgetary Control: A Tool for Cost Control in Manufacturing Companies in Nigeria," Eur. J. Econ., vol. 6, no. 37, pp. 98-109, 2014.

[2] F. A. Mir and A. H. Pinnington, "Exploring the value of project management: Linking Project Management Performance and Project Success," Int. J. Proj. Manag., vol. 32, no. 2, pp. 202-217, 2014.

[3] P. M. Institute, A Guide to The Project Management Body of Knowledge (PMBOK Guide), Sixth. Project Management Institute, Inc: Pennsylvania., 2017.

[4] D. L. Hansen, Don R, Mowen, Maryanne M., Heitger, Cornerstones of Managerial Accounting 6th edition, Third. Southwestern-Cengage Learning, 2015. 
[5] A. Shenhar and V. Holzmann, "The Three Secrets of Megaproject Success: Clear Strategic Vision, Total Alignment, and Adapting to Complexity," Proj. Manag. J., vol. 48, no. 6, pp. 29-46, 2017.

[6] R. M. Johnson and R. I. I. Babu, "Time and cost overruns in the UAE construction industry: a critical analysis," Int. J. Constr. Manag., vol. 20, no. 5, pp. 402-411, 2020.

[7] A. Shenhar and V. Holzmann, "The Three Secrets of Megaproject Success: Clear Strategic Vision, Total Alignment, and Adapting to Complexity," Proj. Manag. J., vol. 48, pp. 29-46, Dec. 2017.

[8] D. Hancock and B. Algozzine, A Practical Guide for Doing Case Study Research. 2006.

[9] K. Neuendorf, The Content Analysis Guidebook. 2002.

[10] E. R. S. PhD, Qualitative and MixedMethod Research Analysis Using Nvivo 11" Handout. CASE WRITING AND METHODOLOGY. University of Indonesia, 2018.

[11] Suryana, Sugiyono, U. Sekaran, S. Lee, T. Stearns, and G. M. Geoffrey, Metode Penelitian Kuantitatif, Kualitatif, dan R\&D. 2013.

[12] R. Rochow et al., FenRIAM full guide Proposal for a Foresight-enriched Research Infrastructure Impact Assessment Methodology, no. May 2014. 2012.

[13] D. W. Williams and T. D. Calabrese, "The status of budget forecasting," J. Public Nonprofit Aff., vol. 2, no. 2, pp. 127-160, 2016.

[14] M. Todorovic, D. Petrović, M. Mihic, V. Obradović, and S. Bushuyev, "Project success analysis framework: A knowledgebased approach in project management," Int. J. Proj. Manag., Nov. 2014. 